\title{
Original
}

\section{Changes in Subcellular Distribution of Atrial Granules in Canine Atrial Muscle Cells after Atrial Pacing -An Immunoelectron Microscopic Study-}

\author{
Juichi Hiroshige, Youichi Takeyama, Shigeo Hasegawa \\ and Takashi KATAGIRI
}

\begin{abstract}
Ultrastructural distribution and nature of atrial granules (AGs) in canine atrial muscle cells were examined by immunoelectron microscopy. Changes in subcellular distribution of AGs after atrial pacing were evaluated relative to the serum level of atrial natriuretic polypeptide (ANP) and atrial pressure. Thirty mongrel dogs were divided into three groups: group A, nonpaced group; group B, paced for $20 \mathrm{~min}$; and group C, paced for $60 \mathrm{~min}$. Atrial pacing was performed at a rate of 300 per minute, and serum ANP levels and hemodynamics were measured before and after the pacing for 10, 20, 40 and $60 \mathrm{~min}$, in groups B and C. Specimens were excised from both atrial appendages and atria at the end of each experiment. Some were prepared for electron microscopy by either the usual transmission method or an immunocytochemical method, and the others were prepared for measurement of tissue concentration of ANP by radioimmunoassay (RIA). In groups B and C, mean right atrial pressure and pulmonary capillary wedge pressure were both significantly higher throughout the pacing. In groups B and C, serum levels of ANP increased rapidly from $24 \pm 11$ to $75 \pm 39 \mathrm{pg} / \mathrm{ml}$ within the first $10 \mathrm{~min}$ of pacing and remained higher, accompanied by higher atrial pressures, during atrial pacing. However, tissue concentration of ANP was not changed significantly by pacing in any part of the atrial tissue. Immunoelectron microscopy revealed that all AGs contained immuno-positive $\alpha$-hANP. In group B, AGs were predominant in the subsarcolemmal area. A number of caveolae, reflecting exocytosis of AGs, were also found along the sarcolemma. In group C, AGs and coated vesicles were increased especially in the Golgi area, suggesting accelerated synthesis of AGs. These results indicate that $\alpha$-ANP containing in AGs are released by exocytosis, and the secretion is promoted by atrial pacing for $20 \mathrm{~min}$, which also results in higher atrial pressures. Synthesis of $\alpha$-ANP is concluded to be stimulated by further pacing for $60 \mathrm{~min}$.
\end{abstract}

Key words: atrial granules, atrial natriuretic polypeptide, immunoelectron microscopy, atrial pacing, canine

\section{Introduction}

Atrial natriuretic polypeptide (ANP) consists of 28 amino acids ${ }^{1)}$ is characterized as potently natriuretic and vasodilative, and has been isolated from atrial myocytes ${ }^{2)}$. The

The 3rd Department of Internal Medicine, Showa University School of Medicine, 1-5-8 Hatanodai, Shinagawa-ku, Tokyo 142, Japan. 
biological activity of ANP was first identified by intravenous administration of atrial extracts in anesthetized rats by DeBold et al. who found it caused surprising diuresis and concomitant natriuresis:3). The peptide was also demonstrated to cause vasodilation and inhibit aldosterone, renin and vasopressin secretion in humans and experimental animals, in response to stimuli that accelerated ANP secretion from atrial myocytes. Thus, ANP is a cardiac hormone related to fluid volume reduction and vasodilation.

Immunocytochemical localization of ANP was demonstrated in atrial myocytes of various animals by Cantin et al. ${ }^{+1}$ Ultrastructual immunocytcchemistry performed by them revealed that this peptide is strictly localized in atrial granules (AGs). Recently, ultrastructural evidence of exocytosis of AGs from myocytes has been shown ${ }^{5)}$, but the precise ultrastructual mechanism of the synthesis of ANP and its reiease from myocytes by various stimuli has not been fully resolved.

Following the determination of the chemical structures of ANP families by Kangawa et al. in $1984^{(i)}$, some investigators determined the concentration of immunoreactive ANP in both plasma and atrial tissue by radioimmunoassay ${ }^{i, s)}$. In addition, many investigators have reported that the major secretory stimuli of ANP from atrial myocytes increases pulmonary capillary wedge pressure, right atrial pressure, and heart rate ${ }^{9,10)}$. However there have been few reports relating myocellular distribution with leveis of ANP, and few immunoelectron microscopic observations. In the present study, in addition to the mechanism of synthesis and release of ANP, of which little is known ultrastructurally, the nature of AGs as well as correlative changes were examined by immunoelectron microscopy.

\section{Materials and Methods}

Animal experiments: Thirty mongrel dogs of both sexes weighing $11-21 \mathrm{~kg}$ were anesthetized with intravenous injection of a mixture of urethane $(450 \mathrm{mg} / \mathrm{kg}), \alpha$-chloralose $(45 \mathrm{mg} / \mathrm{kg})$ and diazepam $(10 \mathrm{mg})$. Ventilation was controlled by a Harvard respiratory pump with room air. Physiological saline was infused by drip infusion $(0.1 \mathrm{ml} / \mathrm{kg} / \mathrm{min})$ and anesthesia was maintained in a steady state by adding anesthetics when necessary. A $7 \mathrm{~F}$ pigtail catheter was placed in the ascending aorta for continuous monitering of aortic pressure. Both pulmonary capillary wedge pressure (PCFP) and right atrial pressure (RAP) were measured with $7.5 \mathrm{~F}$ Swan-Ganz thermodilution catheters. A $6 \mathrm{~F}$ bipolar pacing catheter (Cordis Inc.) was placed in the right atrium (RA) for atrial pacing. The electrocardiogram was continuously monitored throughout the study. After setting these procedures up, baseline measurements of heart rate (HR), atrial pressure (AoP), RAP and PCWP were carried out after $30 \mathrm{~min}$ of resting. A baseline concentration of serum ANP was determined by RIA by sampling blood $(5 \mathrm{ml})$ from the RA through a Swan-Ganz catheter.

Dogs were divided into three groups as follows; non-paced control groups (group A), paced for $20 \mathrm{~min}$ (group B) and paced for $60 \mathrm{~min}$ (group C). Atrial pacing at a rate of 300 beats! min was carried out. The RAP and PCWP were measured at $5 \mathrm{~min}, 10 \mathrm{~min}, 20 \mathrm{~min}$ (for groups $\mathrm{B}$ and $\mathrm{C}$ ), $40 \mathrm{~min}$ and $60 \mathrm{~min}$ (for group $\mathrm{C}$ ) after the beginning of pacing. Blood samples for ANP assay were also taken from the RA at corresponding times. Blood volume removed for sampling was replaced with an equal volume of intravenous saline in a bolus.

The beating heart was removed by left thoractomy immediately after suspension of atrial pacing. Both atrial appendages and atria were excised for ultrastructural immunocytochemistry, and measurement of tissue ANP level. 
Blood and tissue sampling of ANP: Blood samples for ANP assay were withdrawn into pre-chilled syringes and collected in ice-chilled tubes containing ethylenediamine tetraacetic acid- $\mathrm{Na}_{2}$ and aprotinin. The samples were centrifuged at $3,000 \times \mathrm{g}$ for $10 \mathrm{~min}$, and the plasma was separated immediately and stored at $-20^{\circ} \mathrm{C}$ for subsequent analysis of ANP levels by RIA. Excised tissues of right and left atrial appendages and atria (300-600 mg) were immediately weighed and stored at $-70^{\circ} \mathrm{C}$ until extraction. A tissue specimen was homogenized with $20 \mathrm{vol} 0.1 \mathrm{~mol} / \mathrm{L}$ acetic acid containing $1 \%$ Triton $\mathrm{X}-100$, boiled for $5 \mathrm{~min}$ to inactivate protease, and centrifuged at $24,500 \times \mathrm{g}$ for $20 \mathrm{~min}$. The supernatant fluid was stored at $-20^{\circ} \mathrm{C}$ until use.

Radioimmunoassay of the plasma samples and tissue extracted for ANP were measured according to the method described by Miyata et al. ${ }^{11}$

Electron microscopy: Tissue sampling was from bilateral atrial appendages and atria. Immediately after removal of the heart, tissue was cut into small pieces and prefixed in a cold fixative solution of $2 \%$ glutaraldehyde in $0.1 \mathrm{M} \mathrm{Na}$-cacodylate $(\mathrm{pH} 7.4)$ for $2 \mathrm{hr}$ at $4^{\circ} \mathrm{C}$. After rinsing three times in $0.1 \mathrm{M} \mathrm{Na}$-cacodylate $(\mathrm{pH} 7.4)$, blocks were postfixed in $2 \%$ osmium tetroxide $\left(\mathrm{OsO}_{4}\right)$ in $0.1 \mathrm{M}$ cacodylate $(\mathrm{pH} 7.4)$ for $1 \mathrm{hr}$ at $4{ }^{\circ} \mathrm{C}$, dehydrated in a graded series of ethanol and propylene oxide, and embeded in a mixture of Epon-Araldite.

Ultrathin sections were cut from Epon-Araldite-embedded tissues with a Sorball Porterblum ultramicrotome MT-2. Some were mounted on 150-mesh copper grids for conventional processing, and others were picked up on 200-mesh nickel grids prepared for immunocytochemical processing. The nickel grids were pretreated for $30 \mathrm{~min}$ at room temperature with saturated sodium metaperiodate solution for deosmification to enhance antigenicity to immunocytochemical reaction and then processed according to a postembedding immunocolloidal goldstaining method. The grids were immersed in a primary antibody solution, anti-rabbit $\alpha$ hANP anti-serum diluted 1:500 (Peninsula Laboratories, USA), for $24 \mathrm{hr}$ at $4^{\circ} \mathrm{C}$, and then incubated in a secondary antibody solution, gold-labeled goat anti-rabbit IgG solution (1:50, Tokyo Serum Incorp., Japan), for $60 \mathrm{~min}$ at room temperature. In control experiments no immunostaining was observed in any myocyte part including AGs when primary antisera were ommitted and replaced with non-immune serum or preabsorbed with their corresponding antigens for $24 \mathrm{hr}$ at $4{ }^{\circ} \mathrm{C}$. Labelled secondary antisera also exhibited no cross-reactivity with IgG from inappropriate species. Both copper and nickel grids were washed with phosphate buffer solution (PBS) and with distilled water, and then double-stained with uranyl acetate and lead citrate. Specimens were examined with a Hitachi H-300 electron microscope.

\section{Results}

Hemodynamics: Right atrial pacing at a rate of 300 beats/min was carried out for $20 \mathrm{~min}$ in group B, and $60 \mathrm{~min}$ in group C (Fig. 1a). Fig. $1 \mathrm{~b}$ and $1 \mathrm{c}$ illustrate significant changes in PCWP and RAP, respectively. The baseline PCWP was $9.3 \pm 2 \mathrm{mmHg}$, and it began to increase rapidly to $12.8 \pm 3.4 \mathrm{mmHg}(\mathrm{p}<0.01)$ in the first to $10 \mathrm{~min}$ of atrial pacing and remained high during the pacing. Similarly, mean RAP increased from a baseline level of $4.3 \pm 1.5 \mathrm{mmHg}$ to $6.3 \pm 1.9 \mathrm{mmHg}$ at $20 \mathrm{~min}$ of pacing $(\mathrm{p}<0.05)$ and tended to increase until the end of the experiments. In addition to higher mean RAP, systolic RAP was much higher and diastolic RAP was rather lower, resulting in increased distance between systolic and diastolic RAP in the paced groups (B and C).

Serum ANP levels: Changes in serum ANP level are shown in Fig. 1d. Baseline concen- 


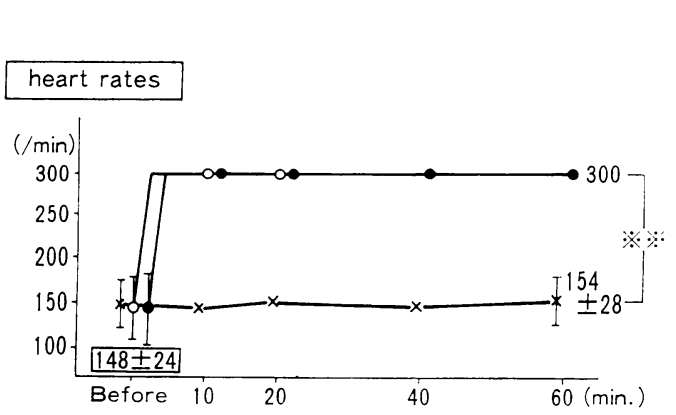

1 .

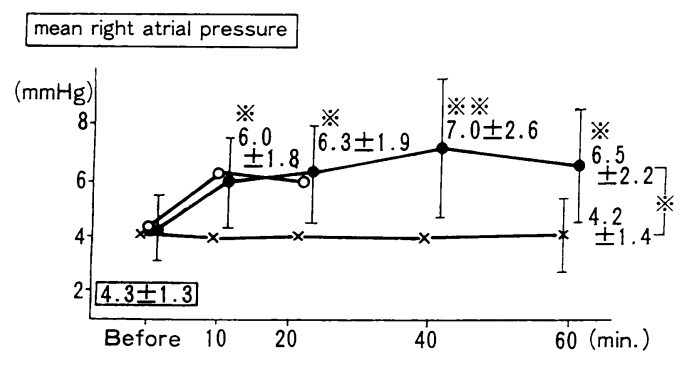

$1 c$.

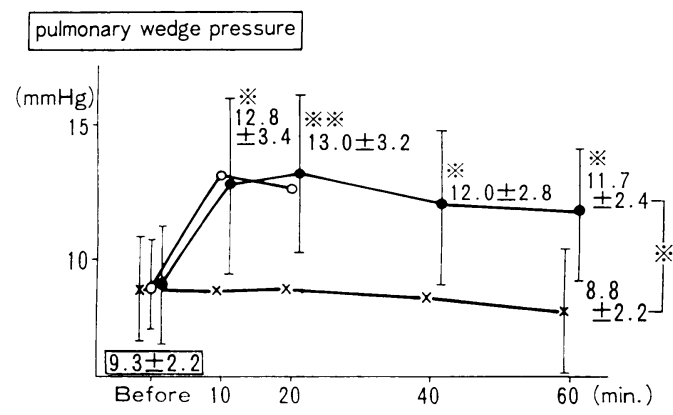

1 b.

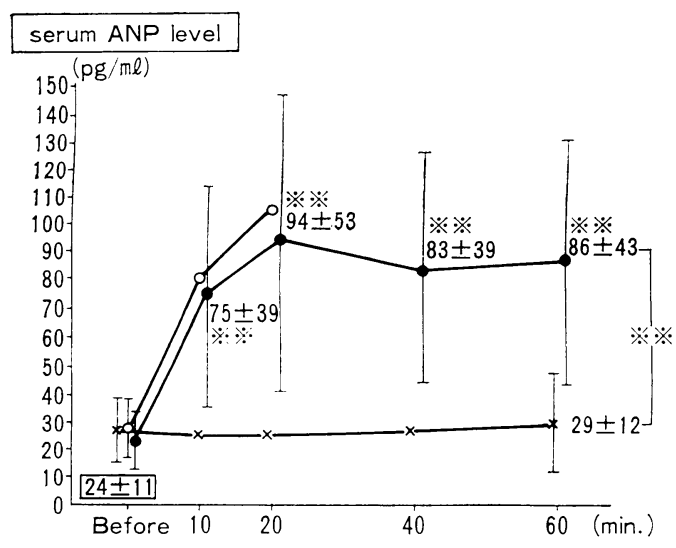

$1 d$.

Group A: $\times-\times$, Group B: $\bigcirc-0$, Group C: $-\bullet, ※: p<0.05, ※ ※ p<0.01$.

Fig. 1a, b, c, d. Time courses of heart rate, pulmonary capillary wedge pressure (PCWP), right atrial pressure (RAP) and serum ANP levels in each group during atrial pacing study. Values are expressed as mean \pm SD. Group A; non-paced control group. Group B; paced for $20 \mathrm{~min}$. Group C; paced for $60 \mathrm{~min}$. PCWP, mean RAP and ANP levels were significantly higher in groups $B$ and $C$.

tration of serum ANP was $24 \pm 11 \mathrm{pg} / \mathrm{ml}$. After initiating the atrial pacing, there were significant increases in serum ANP to $75 \pm 39 \mathrm{pg} / \mathrm{ml}(\mathrm{p}<0.01)$ in the first $10 \mathrm{~min}$, and to $94 \pm$ $53 \mathrm{pg} / \mathrm{ml}(\mathrm{p}<0.01)$ in the second $10 \mathrm{~min}$ of pacing. In group $\mathrm{C}$, ANP level was remained high during the last 40 min of pacing.

In group A, PCWP and mRAP were normal, and there was no significant correlation between pressure and serum ANP concentration. On the contrary, both PCWP and mRAP were increased in groups $\mathrm{B}$ and $\mathrm{C}$ by pacing, and they correlated well with serum ANP level. Fig. 1e shows the correlation between PCWP and serum ANP levels at 20 min of pacing in 20 dogs in groups B and C. Fig. 1f also illustrates a correlation between mRAP and serum ANP level.

Tissue ANP levels: Fig. 2 shows the compariscn of tissue ANP concentration in atrial appendages and atria in the three groups. Baseline tissue ANP level in each appendage tended to be higher than that in either atrium, though the difference was not statistically 


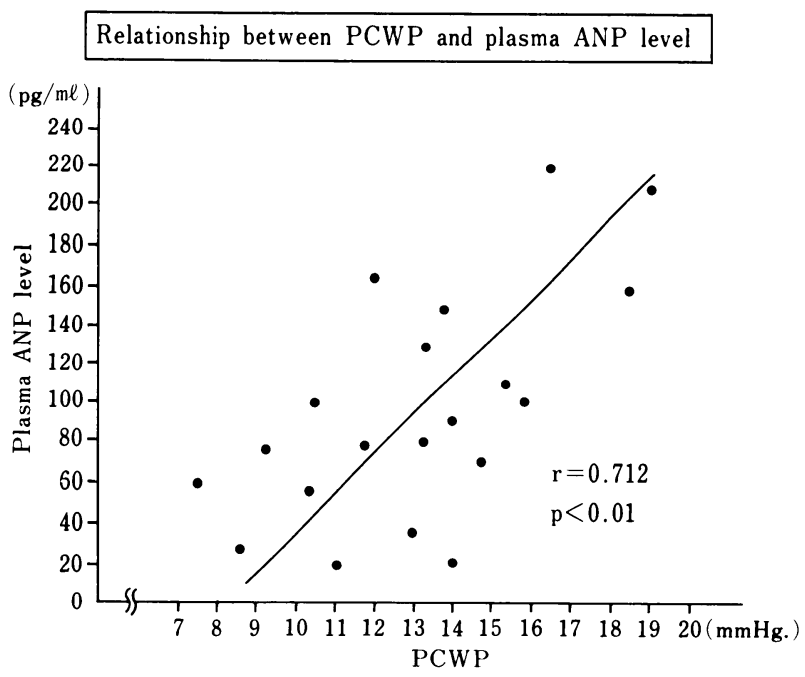

1 e.

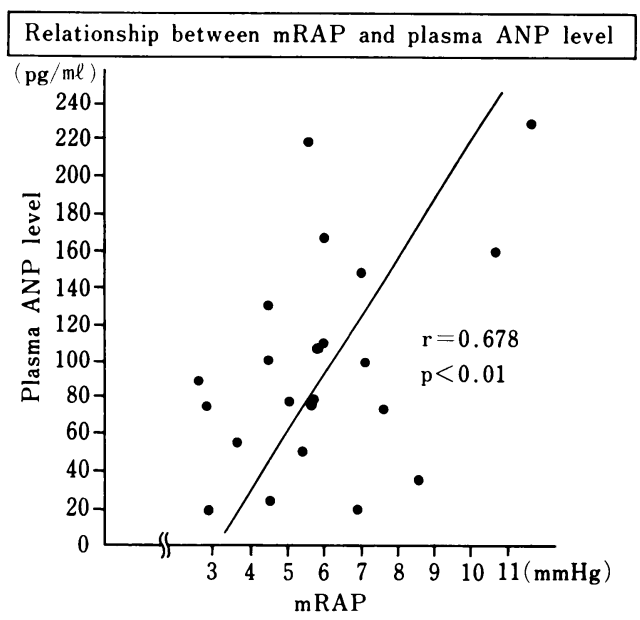

1f.

Fig. 1e, f. Relations between PCWP, RAP and plasma ANP levels.

significant. Tissue concentration of ANP in paced group B tended to be lower than that in group $\mathrm{A}$, but was not significantly different in $\mathrm{B}$ and $\mathrm{C}$ than in the non-paced control group $A$ in either atrial appendages or atria.

Ultrastructual observation: Fig. 3 shows an electron micrograph of a part of a right atrial muscle cell from group A. AGs were scattered in the perinuclear, intermyofibrillar and subsarcolemmal areas in the sarcoplasm of atrial muscle cells. Several AGs were also be found around Golgi apparatus in the perinuclear Golgi complex area in group A, and occasionally around some cisternae of rough-surfaced endoplasmatic reticulum.

Immunoelectron microscopy revealed that all AGs were labeled specifically and abundantly with $15 \mathrm{~nm}$ diameter gold-particles, which reflected the immunoreaction-positive $\alpha$-hANP. As visualized by the colloidal gold-particles, all AGs were confirmed to contain ANP. No 
Tissue concentration of ANP in each atrium and atrial appendage in Group A, B and C
Group A : $\square$

Group B :

Group C: ZZZ

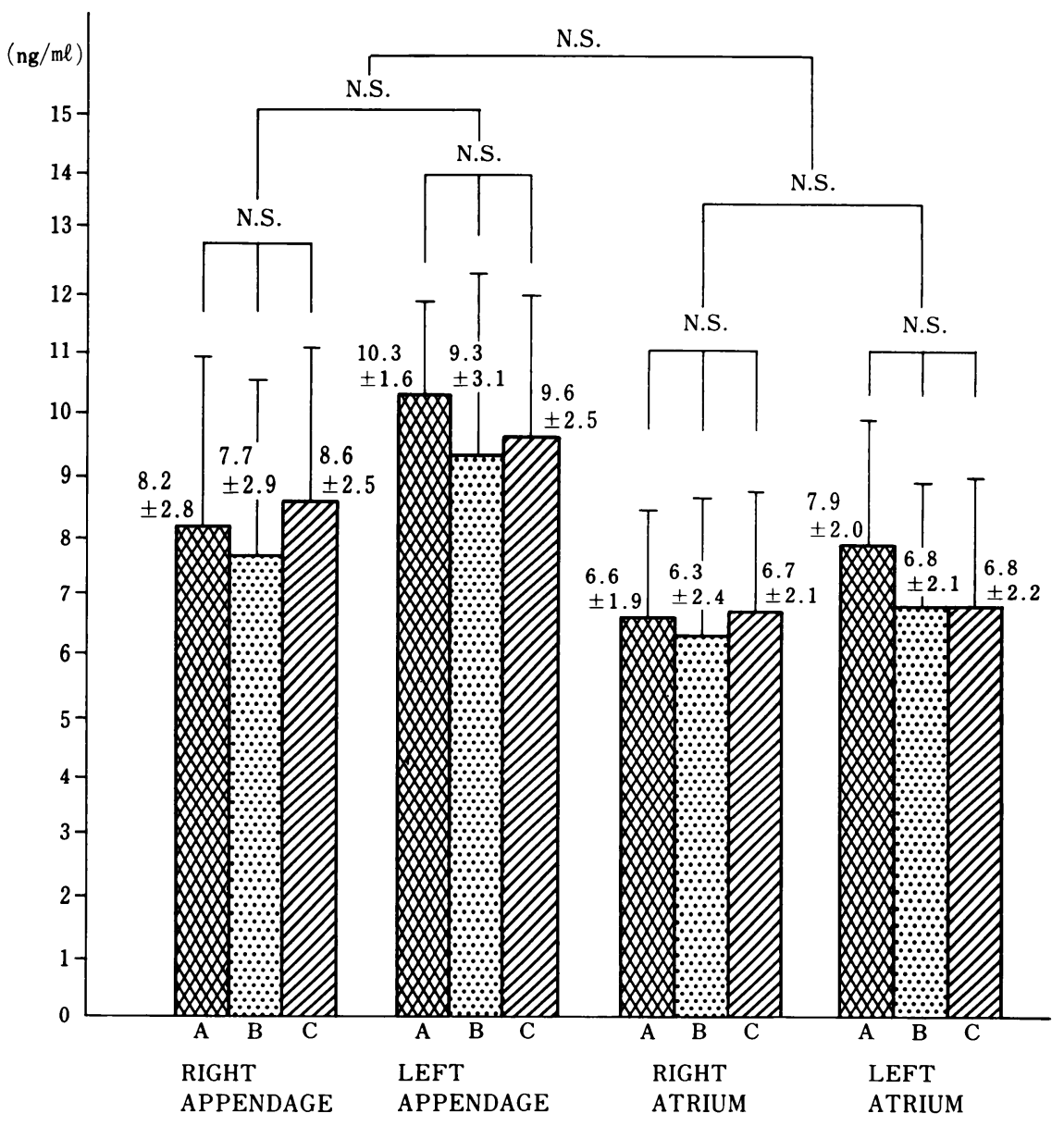

Fig. 2. Tissue concentration of $\alpha$-ANP in both atrial appendages and atria. Group A: non-paced group. Group B: paced for $20 \mathrm{~min}$. Group C: paced for $60 \mathrm{~min}$. There were no significant differences between groups in any atria or atrial appendages.

gold particles were recognized in any other organelles such as lipofuscin granules, lipid droplets and residual bodies in the atrial muscle cells (Fig. 4a, 4b). The intensities of immunoreactions were similar in the right and left atria and atrial appendages, and in all groups.

Substantial changes in the distribution of AGs were recognized in the atrial myocytes of the paced groups. In group B, AGs were increased in number in the subsarcolemmal area. Many caveolae, reflecting the exocytosis of AGs, were also found in this area in group B (Fig. 5a, 5b and 5c). In group C, AGs increased in the Golgi area. Increase of immature AGs was found near the Golgi complexes in the hypersecretory phase. Several buddings from Golgi lamellae, and coated vesicles of various sizes and densities were evident in the Golgi area in myocytes of group C (Fig. 6a, 6b and 6c). 


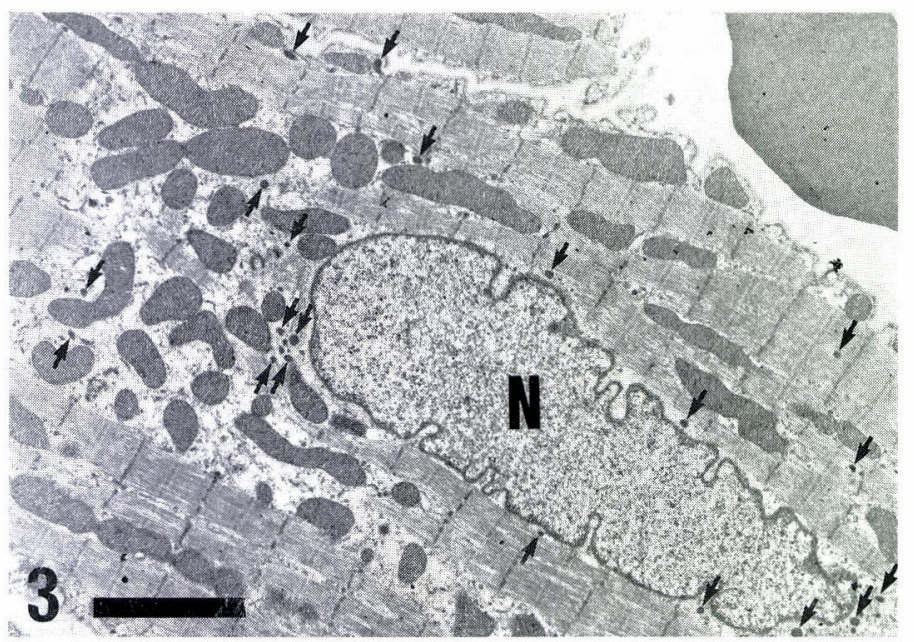

Fig. 3. An electron micrograph of part of a right atrial muscle cell in group A. Atrial granules (arrows, AGs) are seen scattered in the perinuclear, intermyofibrillar and subsarcolemmal areas. $\mathrm{N}$ : nucleus, $\mathrm{Bar}=10 \mu \mathrm{m}$.

\section{Discussion}

As part of the mechanism of release of ANP by atrial pacing, Kisch ${ }^{12)}$, Jamieson and Palade ${ }^{13}$ ) reported that endocrine storage granules were contained in atrial myocytes of all the vertebrates. Physiologic or pathophysiologic roles and functions of these granules remained uncertain for a long time, athough increased urine volume in patients with paroximal atrial tachycardia immediately after the cessation of tachycardia has been empirically well known. DeBold et al. ${ }^{3)}$ indicated that intravenous administration of extracts from rat atrial tissue induced strong natriuresis as well as diuresis. The amino acid sequence of this natriuretic factor, now called ANP, was determined by several groups of investigators (Kangawa et al. ${ }^{2)}$, Flynn and Davies ${ }^{14)}$ ) within three years of the initial report by DeBold et al. In addition, Cantin et al. ${ }^{4)}$ and Morinaga et al. ${ }^{15)}$ demonstrated immunocytochemically that AGs in atrial myocytes have been the main sites of storage as well as synthesis of ANP. Thus, these reports proved that atrial myocytes constitute the major site of synthesis and secretion of ANP.

In the present study, right atrial pacing was carried out to accelerate ANP synthesis and secretion in atrial myocytes in response to higher pressures. It has been found recently that several factors affect the secretion of ANP into the bloodstream.

Many studies indicate that distention of the atrial wall or elevated atrial pressure stimulates the release of ANP. Left atrial wall distention in anesthetized dogs (Ledsome et al. ${ }^{10)}$ ) and distention of either the right or left atrium in conscious dogs (Metzler et al. ${ }^{16)}$ ) caused a marked increase of circulating ANP level.

It has been reported that more frequent atrial contraction could directly influence ANP secretion (Schiebinger and Linden $\left.{ }^{1 \tau}\right)$ ). This fact suggest that increased frequency of atrial contraction might account for a direct role in increasing ANP secretion during clinical episodes of atrial tachycardia in humans ${ }^{18)}$. Roy et al. ${ }^{19)}$ revealed that plasma ANP levels were increased markedly and rapidly during induced supraventricular tachycardia in humans 

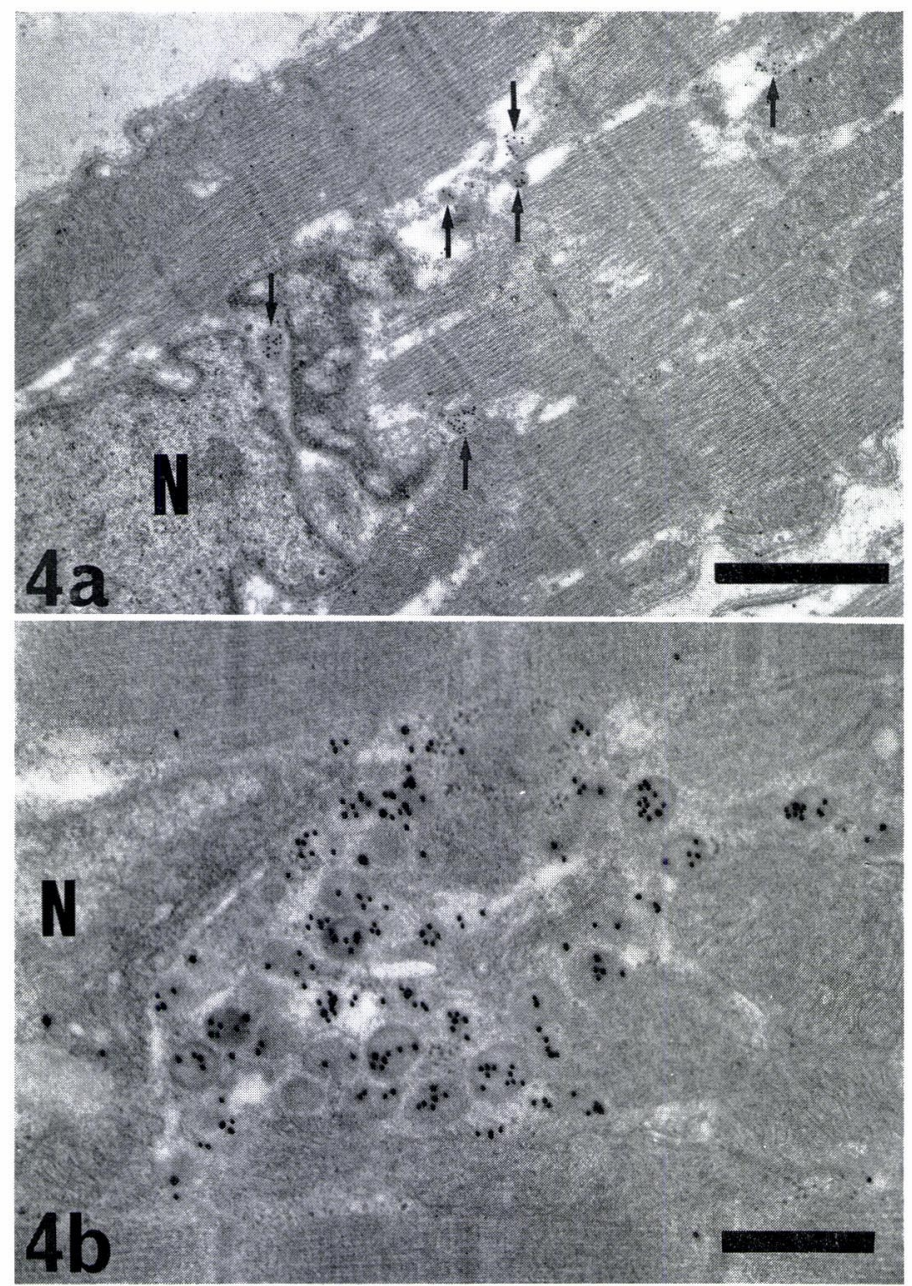

Fig. 4a, b. Immunoelectron micrographs of ANP-like immunoreactive AGs labeled with gold particles of about $15 \mathrm{~nm}$ diameters. ANP-like immunoreactivity is localized to AGs. 4a: AGs (arrows) were scattered in a left atrial myocyte in group A. N: nucleus, Bar= $1 \mu \mathrm{m}$. 4b: Golgi area in right atrium in group C. Many immunoreactive AGs were seen in the field. $\mathrm{N}$ : nucleus, $\mathrm{Bar}=1 \mu \mathrm{m}$.

associated with higher right atrial pressure. Atrial pacing was also performed by some investigators. Espiner et al. ${ }^{9)}$ and Ellenbogen et al. ${ }^{20)}$ revealed that atrial pacing rates above 125-140 beats/min in humans were strong and potent stimuli for ANP release.

In our preliminary investigation, with atrial pacing at a rate of 220 beats/min, no significant increase in plasma ANP level was recognized without elevation in atrial pressure. However, during right atrial pacing at 300 beats/min both mRAP and PCWP were significantly associated with an increase of serum ANP level. It may be inferred that only an increase in the heart rate itself is not an effective stimulus to release ANP in our experiment. Mean atrial pressure has generally been used as an index of atrial wall stretch. Our results also provide additional support for the concept that electrical pacing of the atrium 

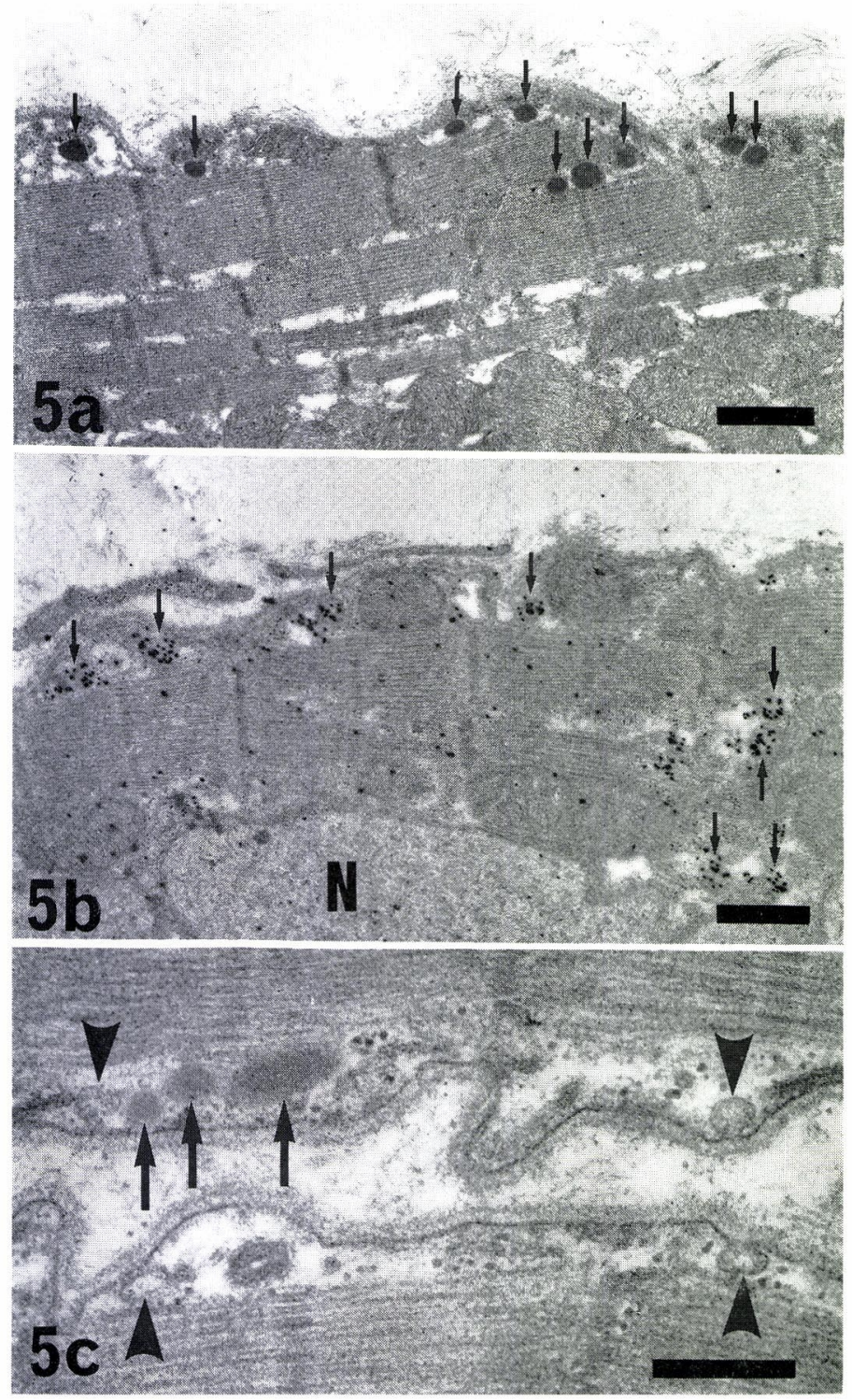

Fig. 5. Several AGs (arrows) are seen in the subsarcolemmal area in group B.

5a: An EM of a myocyte of right atrial appendage. $\mathrm{Bar}=1 \mu \mathrm{m}$. 5b: An immuno $\mathrm{EM}$ of a right atrial myocyte. $\mathrm{N}$ : nucleus, $\mathrm{Bar}=1 \mu \mathrm{m} .5 \mathrm{c}$ : $\mathrm{AGs}$ and caveolae (arrowheads) suggesting exocytosis in the subsarcolemmal area. Caveolae are common and well defined in the sarcolemmal membranes of atrial myocytes in group B. $\mathrm{Bar}=1 \mu \mathrm{m}$.

causes acute change of atrial stretch, resulting in a potent stimulus for ANP release. However, it is difficult to convincingly demonstrate an independent effect with the atrial pacing rate, electrical stimulation and atrial contractility as stimuli for ANP release.

The mean plasma ANP level in groups B and C was three times that in group A within $20 \mathrm{~min}$ after initiation of the atrial pacing and throughout the study for $60 \mathrm{~min}$. Former 

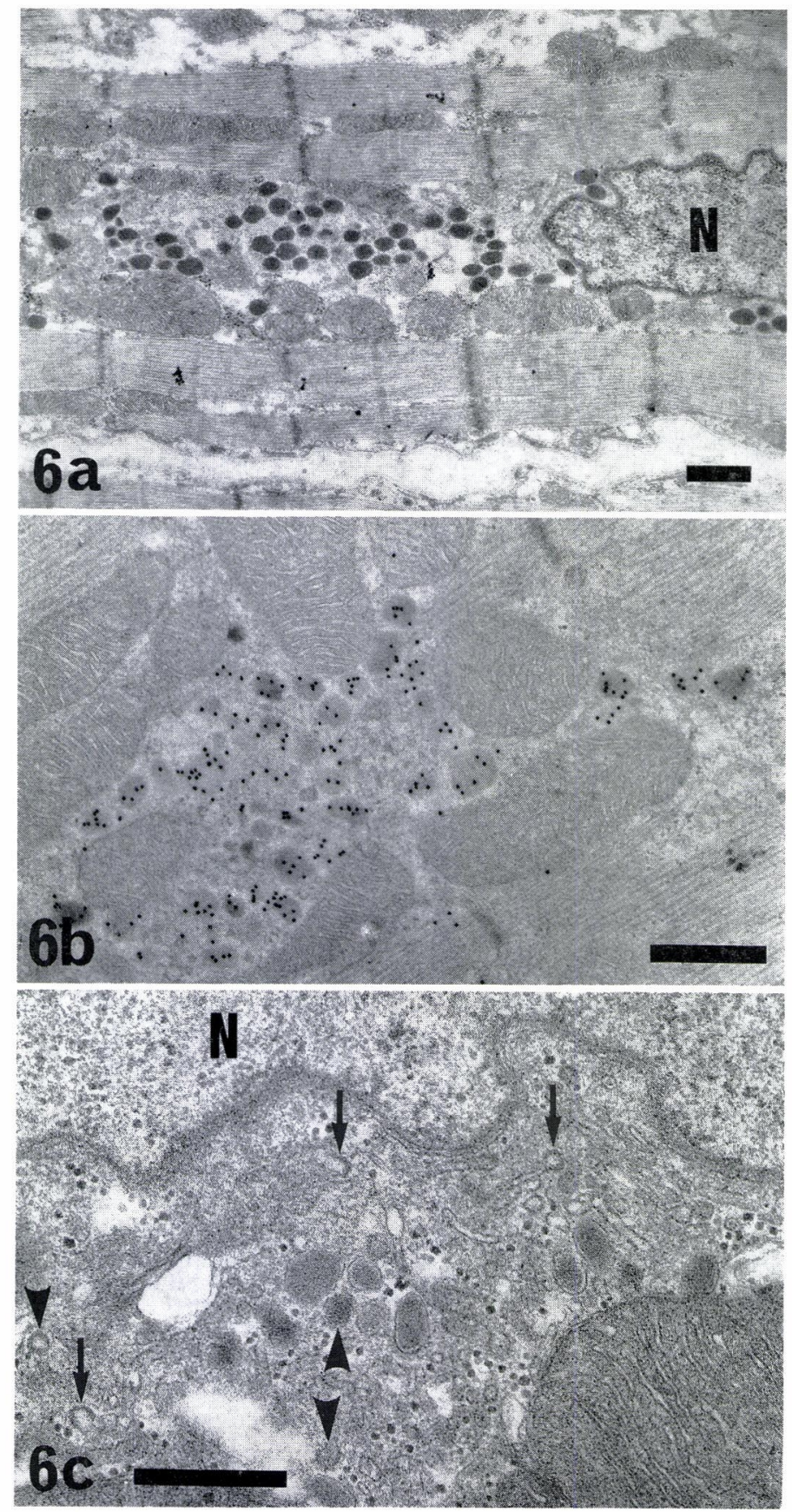

Fig. 6a, b. Significant increase in number of AGs in the Golgi area.

6a: An electron micrograph of right atrial myocyte. $\mathrm{N}$ : nucleus, $\operatorname{Bar}=1 \mu \mathrm{m} .6 \mathrm{~b}: \mathrm{An}$ immuno-electron micrograph of right atrial myocyte. $B a r=1 \mu \mathrm{m}$.

Fig. 6c. Higher magnification of Golgi area showing some budding (arrows) and coated vesicles (arrowheads) in a left atrial myocyte in group C, showing features of pinching off immature AGs from Golgi apparatus. N: nucleus, Bar $=1 \mu \mathrm{m}$. 
studies $^{21)}$, using bolus injection or infusion of $\alpha$-ANP and venous measurements of ANP levels, indicate that $t=1 / 2$ is 3 minutes. These results suggest that atrial pacing accompanied by higher atrial pressures may have been acute and continuous stimulation for ANP release during our experiment.

Change in the distribution of atrial granules: Since the first ultrastructual report on AGs in guinea pig atrial myocytes by $\mathrm{Kisch}^{12)}$ in 1956, AGs, originally called 'microbodies' or 'atrial specific granules', have been observed in various mammalians by electron microscopy. A few authors have described the nature of $A G$ in dog hearts (Jamieson and Palade ${ }^{13)}$; Bencosme and Berger ${ }^{22)}$ ). In canine atrial myocytes, the endocrine secretory apparatus is relatively scarce compared with that of other species. In our observation of the non-paced control group A, AGs were sparsely scattered in atrial myccytes. The most densely localized AGs were found in the vicinity of the nuclear poles, close or adjacent to the poorly developed Golgi apparatus. A few AGs were also found among myofibrils and distributed closely to the subsarcolemmal area. A distinct figure of typical exocytosis in rat was shown by Paget et al.5), but in the present study exocytotic figures were rarely encountered, particularly in the control group (Fig. 1). We carried out atrial pacing to observe acute alterations in the ultrastructual distribution of AGs.

Several groups of investigators have studied the ultrastructural links between the effects of pharmacologic agents (isoproterenol, propranolol and reserpine, etc.) and changes in the distribution of $\mathrm{AGs}^{2.3)}$. Marie et al. $^{24)}$ first reported the change in electrolyte and water balance in rats accompanying the alteration of both distribution and quantity of AGs. An increase in number of the granules in rat atrial myocytes has been noted during the suppression of release of ANP caused by water deprivation ${ }^{25)}$. Skepper et al. ${ }^{26)}$ and Agnoletti et al. $^{27)}$ reported that expansion of the blood volume causes an increase in the proportion of peripherally located AGs in atrial myocytes. However, there have been a few reports of the alteration of distribution of AGs by acute stimulation such as atrial pacing.

In this study, we observed changes in ultrastructual localization and recognized a focal increase in the number of AGs. AGs were predominantly gathered in subsarcolemmal areas in group B, and many caveolae reflecting the exocytosis of AGs were also found along the sarcolemma, suggesting active and immediate movement of secretory granules from the perinuclear Golgi area of the atrial cell to the subsarcolemmal area by atrial pacing. The centrifugal movement of the secretory granules is thought to occur rapidly, at least within 20 minutes.

In group $\mathrm{C}$, we observed significant changes in both distribution and number of AGs, not only in subsarcolemmal but also in perinuclear areas. The present results agree with the reports of Berger and Rona ${ }^{28)}$. Theron et al. ${ }^{29)}$ reported that immature specific vesicles or granules develop from Golgi complex by 'budding off'. In the present study, much budding from the Golgi lamellae and coated vesicles appeared at various densities in the Golgi area of atrial myocytes, especially in group C. This undoubtedly reflected the synthetic acceleraticn of ANP. These findings were not observed in group A, but we occasionally observed activated Golgi apparatus in group B. Functional activation of the Golgi apparatus, indicating production of AGs, was observed at least within 20 or 60 minutes.

There were no statistically significant differences in tissue ANP level in atrial tissues between control (group A) and either paced group (group B or C). This possibly indicated equilibrium between release and synthesis of ANP during the pacing. It is also conceivable 
that there was an increase in the number of AGs in group B in the subsarcolemmal area, and the significantly higher level of serum ANP during an unchanged tissue ANP level, could be ascribed to a huge amount of storage of ANP in the tissues.

In summary, these results suggest that ANP-containing AGs are released by exocytosis, and the secretion might be promoted by atrial pacing for $20 \mathrm{~min}$, which results in higher atrial pressure, increased heart rate, atrial contractility and wall stretching. The synthesis of ANP is also considered to be stimulated by further pacing for 60 minutes, while the equilibrium of ANP concentration is maintained in the atrial tissues.

\section{Acknowledgments}

The authors sincerely thank Professor Yasumitsu Nakai of Showa University School of Medicine and Professor Hisayuki Matsuo of Miyazaki Medical College for their kind guidance and encouragement in this work, and we are greatly indebted to Drs. Seiji Shioda, Kaoru Akimoto, Kazuhiko Umetsu and Mamoru Mochizuki for their collaboration.

\section{References}

1) Richards AM, Nicholls MG, Ikram H, Webster MWI, Yandle TG and Espiner EA: Renal, hemodynamic, and hormonal effects of human alpha atrial natriuretic peptide in healthy volunteers. Lancet, 1: $545-548$ (1985)

2) Kangawa $\mathrm{K}$ and Matsuo $\mathrm{H}$ : Purification and complete amino acid sequence of alpha-human atrial natriuretic polypeptide (alpha-hANP). Biochem Biophys Res Commun, 118: 131-139 (1984)

3) DeBold AJ, Borenstein HB, Veress AT and Sonnenberg H: A rapid and potent natriuretic response to intravenous injection of atrial myocardial extract in rats. Life Sci, 28: 89-94 (1981)

4) Cantin M, Gutkowska J, Thibault G, Milne RW, Ledoux S, MinLi S, Chapeau C, Garcia R, Hamet P and Genest $\mathrm{J}$ : Immunocytochemical localization of atrial natriuretic factor in the heart and salivary glands. Histochemistry, 80: 113-127 (1984)

5) Page E, Goings GE, Power B and Upshaw-Early J: Ultrastructual features of atrial peptide secretion. Am Physiol, 251: H340-348 (1986) $\quad \therefore \cdots, \cdots, \ldots, \ldots, \ldots, \cdots, \cdots$,

6) Kangawa K, Fukuda A, Kubota I, Hayashi $\mathrm{Y}$ and Matsuo $\mathrm{H}$ : Identification in rat atrial tissue of multiple forms of natriuretic polypeptides of about 3,000 daltons. Biochem Biophys Res Commun, 121: $585-592$ (1984)

7) Lang RE, Tholken H, Ganten D, Luft HR, Ruskoaho $H$ and Unger $T$ : Atrial natriuretic factor a circulating hormone stimulated by volume loading. Nature, 314: 264-266 (1985)

8) Anderson JV, Christofides ND, Vinas P, Wharton J, Varndell IM, Polak JM and Bloom SR: Radioimmunoassay of alpha rat atrial natriuretic peptide. Neuropeptides, 7: 159-173 (1986)

9) Espiner EA, Crozier IG, Nicholls MG, Cuneo R and Yandle TG: Studies on the secretion, metabolism and action of atrial natriuretic peptide in man. J Hypertens, 4: S85-89 (1986)

10) Ledsome JR, Wilson N, Courneya CA and Rankin AF: Release of atrial natriuretic peptide by atrial distention. Can J Pharmacol, 63: 739-742 (1985)

11) Miyata A, Kangawa $K$, Toshimori $T$, Hatoh $T$ and Matsuo $H$ : Molecular form of atrial natriuretic polypeptide in mammalian tissues and plasma. Biochem Biophys Res Commun, 129: 248-255 (1985)

12) Kisch B: Electron microscopy of the atrium of the heart; guinea pig. Exp Med Surg, 14: 99-112 (1956)

13) Jamieson JD and Palade GE: Specific granules in atrial muscle cells. J Cell Biol, 23: 151-172 (1964)

14) Flynn TG and Davies PL: The biochemistry and molecular biology of atrial natriuretic factor. Biochem J, 232: 313-321 (1985)

15) Morinaga S, Tsumuraya M, Nakajima T, Simosato Y, Yoshinaga K, Abe K, Ohno H and Kanai A: Immunohistochemical and immunocytochemical localization of atrial natriuretic polypeptide in human adult and fetal hearts. Acta Histochem Cytochem, 18: 605-613 (1985)

16) Metzler CD, Lee ME, Thrasher TN and Ramsey DJ: Increased right or left atrial pressure stimulates release of atrial natriuretic peptides in conscious dogs. Endocrinology, 119: 2396-2398 (1986) 
17) Schiebinger RJ and Linden J: Effect of atrial contraction frequency on atrial natriuretic peptide secretion. Am J Physiol, 249: H1095-1099 (1986)

18) Yamaji $T$, Ishibashi $M$, Nakaoka $H$, Imataka $K$, Amano $M$ and Fujii $J$ : Possible role for atrial natriuretic peptide in polyurea associated with paroxysmal atrial arrhythmias. Lancet, 1: 1211 (1985)

19) Roy D, Paillard F, Cassidy D, Bourassa MG, Gutkowska J, Genest J and Cantin M: Atrial natriuretic factor during atrial fibrillation and supraventricular tachycardia. J Am Coll Cardiol, 9: 509_ 514 (1987)

20) Ellenbogen KA, Mohanty PK, Sower JR, Walsh $M$ and Thames MD: Atrial natriuretic factor release is enhanced by incremental atrial pacing. Am Heart J, 116: 489-496 (1988)

21) Yandle TG, Richards AM and Nicholls MG: Metabolic clearance rate and plasma half life of alpha-human atrial natriuretic peptide in man. Life Sci, 38: 1827-1833 (1986)

22) Bencosme SA and Berger JM: Specific granules in mammalian and non-mammalian vertebrate cardiocytes. Methods Achiev Exp Pathol, 5: 173-213 (1971)

23) Okamoto $\mathrm{H}$ : An electron microscopic study of the specific granules in the atrial muscle cell upon the administration of agents affecting autonomic nerves. Arch Histol Jpn, 30: 467-478 (1969)

24) Marie JP, Guillemot H and Hatt PY: La Degré de granulation des cardiocytes auriculaire; étude planimetrique au cours des differentes apports d'eau et de sodium chez le rat. Pathol Biol (Paris), 24: 549-554 (1976)

25) De Bold AJ: Heart atria granularity effects of changes in water-electrolyte balance. Proc Soc Exp Biol Med, 161: 508-511 (1979)

26) Skepper JN, Navaratnam V and Martensz ND: Effect of expansion of blood volume and bilateral vagotomy on specific heart granules and release of atrial natriuretic peptide in the rat. Cell Tissue Res, 258: 211-218 (1989)

27) Agnoletti G, Ferrari R, Slade AM, Severs NJ and Harris P: Stretch induced centrifugal movement of atrial specific granules a preparatory step in atrial natriuretic peptide secretion. J Mol Cell Cardiol, 21: 235-239 (1989)

28) Berger JM and Rona G: Functional and fine structural homogeneity of atrial cardiocytes. Methods Achiev Exp Pathol, 5: 540-590 (1971)

29) Theron JJ, Biagio R, Myer AC and Boekkooi S: Ultrastructual observations on the maturation of granules in atrial myocardium. J Mol Cell Cardiol, 10: 567-572 (1978)

[Received July 7, 1992: Accepted October 19, 1992] 